\title{
Performing the aporias of the archive: Towards a future for South African music archives
}

\author{
Lizabé Lambrechts*
}

\begin{abstract}
National memory is continuously contested in South Africa and archives and museums are often called upon to store objects or material remnants of similarly contested pasts or histories. In addition, these institutions may already have collections that could be seen as contentious. If we consider these institutions as places where history is produced, what should be done with these objects and collections in a democratic country? This article provides a critical enquiry into the systems through which these objects are produced/recorded, appraised, catalogued and preserved as one methodology through which we can engage more fully with how these resources can be mobilised in the present. As a case study, the article will look at the International Library of African Music (ILAM), arguably one of the most important music archives in South Africa. The largest portion of ILAM's holdings comprises field recordings collected by Hugh Tracey, a scholar who is both celebrated and contested. This paper proposes that through engaging with the processes and ambivalence inherent in Hugh Tracey's recording and classification methods, ILAM has the capacity to provide critical and nuanced insight into one of the most important collections of music in southern-Africa.
\end{abstract}

Keywords: Music archive; post-colonial discourse, International Library of African Music (ILAM); critical engagement; archival systems; cataloguing; classification; performance.

\footnotetext{
Dr Lizabé Lambrechts is a Volkswagen Stiftung Research Fellow at Stellenbosch University and serves as the vice-chairperson for the South African Society for Research in Music. She is the project manager of the Hidden Years Music Archive Project (HYMAP) at the Documentation Centre for Music, Stellenbosch University. Her current research is focused on investigating popular music communities in South Africa through an oral history project of the musicians documented in the HYMAP collection, and extensive archival work.
}

\section{How to cite this article:}

L. Lambrechts, "Performing the aporias of the archive: Towards a future for South African music archives", Historia 61, 1, May/Mei 2016, pp 132-154.

http://dx.doi.org/10.17159/2309-8392/2016/v61n1a10

Copyright: (CThe Author(s). Published under a Creative Commons Attribution Licence. 


\section{Opsomming}

In Suid-Afrika, waar die nasionale geheue op 'n kontinue basis betwis word, word daar gereeld op argiewe en museums 'n beroep gedoen om objekte of materiële oorblyfsels van gekontesteerde verledes en geskiedenisse te berg. Boonop het argiewe reeds versamelings in hulle besit wat beskou kan word as omstrede. Indien ons hierdie instansies beskou as plekke waar geskiedenis geproduseer word, wat moet met hierdie objekte en versamelings gebeur in 'n demokratiese land? Hierdie artikel oorweeg die moontlikhede wat gebied word deur 'n kritiese ondersoek na die sisteme waardeur hierdie objekte geskep, beoordeel en gekatalogiseer en bewaar word, as een metodologie waardeur daar meer volledig omgegaan kan word met die wyses waarop hierdie bronne in die hede gemobiliseer kan word. As 'n gevallestudie, kyk hierdie artikel na die International Library of African Music (ILAM), een van die belangrikste musiekargiewe in die land. Die grootste deel van ILAM se versameling bestaan uit veldopnames wat gemaak is deur Hugh Tracey, 'n figuur wat beide gevier en betwis word. Die artikel stel voor dat, deur om te gaan met die prosesse en ambivalensie wat inherent deel van Hugh Tracey se opneem- en klassifikasie metodes was, ILAM oor die kapasiteit beskik om kritiese en genuanseerde insigte te lewer op een van die belangrikste versamelings van musiek in suidelike Afrika.

Sleutelwoorde: Musiekargief; post-koloniale diskoers; International Library of African Music (ILAM); kritiese navorsing; argiefsisteme; katalogisering; klassifikasie; performatiwiteit.

\section{Introduction}

South African archival institutions have always been sites of ideological engagement. Scholarly work has shown how archives have been used to disempower and silence the histories of the majority of the population while under colonial and apartheid rule. Conversely, since the advent of democracy in 1994, archives in South Africa have participated in efforts directed towards reconciliation and the acknowledgement of the history and value of all its citizens. However, this is a contentious project, as it implies coming to terms with the tensions between the past, present and future in a young democracy where archival practice has to confront the complex problems of post-apartheid South Africa, new technological developments and daunting economic challenges.

Two recent public reactions to "artefacts" from the colonial and apartheid eras raise interesting questions on the role envisioned for archival institutions. In $2009 / 2010$ the performances of a polemical song, "Dubul' Ibhunu" 1 by the then ANC Youth League president, Julius Malema and his followers at rallies, received wide media coverage. Performances of the song sparked threats of hate-speech and invoked fears of racial polarisation and renewed outbreaks of racial tension and violence. Among these reactions, the secretary general of the ANC, Gwede Mantashe,

1. The English translation is "Shoot the Boer". 
called for the song to be archived in a responsible and professional manner. ${ }^{2}$ More recently, Achille Mbembe, during a talk on decolonising South African universities, expressed the view that the statue of Cecil John Rhodes on the University of Cape Town's campus, "and the statues of countless men of his ilk that are littering the South African landscape, properly belong in a museum". Although he noted that South African museums have not yet been thoroughly critiqued, he pointed out that "a museum properly understood is not a dumping place. It is not a place where we recycle history's waste. It is first and foremost an epistemic space". He continued by saying that putting contentious objects in such places "would in turn allow us to move on and re-create the kind of new public spaces required by our new democratic project". ${ }^{3}$

Both these responses refer to archival institutions as solutions for contested representations of the past serving democratic projects of nation-building. Apart from being tasked with taking on objects such as those mentioned, archival institutions already have similarly charged objects and even entire collections in their holdings. If we regard these institutions as places where history is produced, where knowledge is created and instituted, as suggested by Mbembe, what should be done with these objects and collections in the archives of a democratic country?

In order to approach these questions, this article proposes that first, it is important to understand and interrogate the processes whereby the archive is produced and certain objects acquired. This approach falls within the purview of scholarship that views archives not simply as sources, but "as technologies of rule in themselves". ${ }^{4}$ Within this discourse, ${ }^{5}$ archives are exposed as "intermediaries

2. F. Robinson, "RSG Praat Saam oor die Nadraai van die Moord op die AWB Leier Eugene Terre'blanche”, 6 April 2010, http://www.rsg.co.za/programmeklank soek.asp?id=75 (accessed 15 April 2010).

3. A. Mbembe, "Decolonizing Knowledge and the Question of the Archive", at http://wiser.wits.ac.za/system/files/Achille\%20Mbembe\%20-\%20Decolonizing\%20 Knowledge\%20and\%20the\%20Question\%20of\%20the\%20Archive.pdf (accessed 10 December 2015).

4. L-A. Stoler, "Colonial Archives and the Arts of Governance: On the Content in the Form”, in C. Hamilton, V. Harris, J. Taylor, M. Pickover, G. Reid and R. Saleh (eds), Refiguring the Archive (David Philip, Cape Town, 2002) p 83.

5. For some examples see the special issue of Social Dynamics, 41, 1 (2015), on sound archives; Hamilton et al. (eds), Refiguring the Archive; C. McEwan, "Building a Postcolonial Archive? Gender, Collective Memory and Citizenship in Post-Apartheid South Africa", Journal of Southern African Studies, 29, 3 (2003), pp 739-757; V. Harris, "Jacques Derrida Meets Nelson Mandela: Archival Ethics at the Endgame," Archival Science, 11 (2011), pp 113-124; V. Harris, Archives and Justice: A South African Perspective (Society of American Archivists, Chicago, 2009); and V. Harris, "Seeing (in) Blindness: South Africa, Archives and Passion for Justice," Archifacts (2001), pp 1-13; L-A Stoler, Along the Archival Grain: Epistemic Anxieties and Colonial Common-sense (Princeton University Press, Princeton: NJ, 2009); Stoler, "Colonial Archives", in Hamilton et al. (eds), Refiguring the Archive, pp 83-102; A. Burton, "Introduction", in A. Burton (ed.), Archive Stories: Facts, Fictions, and the Writing of History (Duke 
between a subject and its later interpreters, a function/role that is one of interpretation itself". ${ }^{6}$ Therefore, scholars increasingly began to point out that the knowledge practices and technologies that form the core of archival practice should not simply be regarded as neutral processes, but as practices that function within and serve to express, relations of power. ${ }^{7}$ As Antoinette Burton notes,

archives do not simply arrive or emerge fully formed; nor are they innocent of struggles for power in either their creation or their interpretive applications ... all archives come into being ... as a result of specific political, cultural, and socioeconomic pressures. ${ }^{8}$

These pressures are mediated by archivists and archival processes, such as the people who created the archive, the systems conceived in place to turn objects into archival material worthy to be kept in a public space (while other documents are discarded) and worthy of the researchers who use them. Taking into account that archives are mediated both internally within dynamic relationships between creators, archivists and users, as well as through the society and historical context wherein they are created, archives and archivists cannot be regarded as impartial custodians of documents and information but should be considered as sites active in framing and producing knowledge. In other words, as Verne Harris points out, the archive "never speaks to us as a thing in and of itself. It speaks to us through the specificities of particular relations of power and societal dynamics". ${ }^{9}$ Archival practices such as selection, classification, ordering and description can therefore expose the "logic" of

University Press, Durham, 2005) pp 1-24; S. Jones, D. Abbott and S. Ross, "Redefining the Performing Arts Archive”, Archival Science, 9 (2009), pp 165-171; R. Hardiman, "En mal d'archive: Postmodernist Theory and Recordkeeping," Journal of the Society of Archivists, 30, 1 (2009), pp 27-44; T. Cook, "We are What we Keep; We Keep What We are: Archival Appraisal Past, Present, Future", Journal of the Society of Archivists, 32, 2 (2011), pp 173-189; T. Nesmith, "Seeing Archives: Postmodernism and the Changing Intellectual Place of Archives", American Archivist, 65, 1 (2002), pp 24-41; J.M. Schwartz and T. Cook, "Archives, Records and Power: The Making of Modern Memory", Archival Science, 2 (2002), pp 1-19; M. Hedstrom, "Archives, Memory, and Interfaces with the Past", Archival Science, 2 (2002), pp 21-43.

6. E. Kaplan, "Many Paths to Partial Truths: Archives, Anthropology, and the Power of Representation", Archival Science, 2 (2002), p 217.

7. The power of the archive has been investigated by numerous scholars such as Stoler, "Colonial Archives", where she explores the archive as a state ethnography; and similarly T. Richards, "Imperial Archive: Knowledge and the Fantasy of Empire (Verso, New York and London, 1993). For other examples, see Hamilton et al. (eds), Refiguring the Archive; Burton (ed.), Archive Stories; V. Harris, Exploring Archives: An Introduction to Archival Ideas and Practice in South Africa (National Archives of South Africa, Pretoria, 2000); and V. Harris, "The Archival Sliver: Power, Memory, and Archives in South Africa", Archival Science, 2, 1/2 (2002), pp 63-86. See also the two special issues of the journal, Archival Science, 1 (2002) and 2 (2002), entitled "Archives, Records, Power".

8. Burton, "Introduction," p 6.

9. Harris, "Seeing (in) Blindness", p 4. 
the archive revealing these systems as cultural constructs. ${ }^{10}$ Uncovering these processes allows us to consider the complicities and complexities of an archive, its systems and its objects, in order to engage more fully with how these resources can be mobilised in the present.

As a case study, I shall look at the International Library of African Music (ILAM), located in Grahamstown, South Africa. ILAM is arguably one of the most important music archives in the country, and also the earliest example of an archive dedicated solely to the preservation of sound material on the continent. ILAM was established in 1954 by Hugh Tracey who emigrated from England to South Africa after the First World War. Initially working on his brother's tobacco farm in Zimbabwe (then Southern Rhodesia), Tracey gradually became interested in the music of the local farm workers and began to record their music. Following in the tradition of the European folklorists, Tracey continued recording music, venturing out into most of sub-Saharan Africa. ${ }^{11}$ Through the years, ILAM has become an international centre for Africanist scholars, teachers, composers and performers. However, Tracey's field recordings collected in colonial Africa and apartheid South Africa are also the source of some ambivalence: on the one hand they represent the achievement of a "musical explorer", "collector" and "conservationist"; on the other the collection is seen as evidence of an "imperialist exploiter of 'Other People's' cultures, a colonialist, a puritanical preservationist". ${ }^{12}$

10. See for example the work of Stoler, "Colonial Archives", where she notes that the content of the archive, how it is preserved and how it is classified can be read as markers of colonial politics.

11. C. Lucia (ed.), The World of South African Music, a Reader (Cambridge Scholars' Press, Newcastle-upon-Tyne, 2005), p 44.

12. These remarks made by Christine Lucia formed part of a speech she made in May 2011 at ILAM. They address some of the core issues at stake in exploring ILAM as a site of cultural production. For similar engagements with Tracey's legacy, see G. Felber, "Tracing Tribe: Hugh Tracey and the Cultural Politics of Retribalisation", SAMUS, 30/31 (2010 and 2011), pp 31-43; P. Peek, Book Review of H. Tracey (with A Tracey and G. Kubik), Codification of African Music and Textbook Project: A Primer of Practical Suggestions for Field Research (International Library of African Music, Roodepoort, 1969), in Ethomusicology, 14, 3 (1970), pp 504-507; H. Pantaleoni and A. Tracey, Book Review of H. Tracey, Codification of African Music and Textbook Project: A Primer of Practical Suggestions for Field Research, in African Music, 5, 1 (1971), pp 95-98; V. Erlmann, African Stars: Studies in Black South African Performance (University of Chicago Press, Chicago, 1991); K. Agawu, "Contesting Difference: A Critique of Africanist Ethnomusicology", in M. Clayton, T. Herbert, and R. Middleton (eds), The Cultural Study of Music: A Critical Introduction (Routledge, New York and London, 2003), pp 227-237; K. Agawu, Representing African Music: Postcolonial Notes, Queries, Positions (Routledge, New York and London, 2003); N. Lobley, "The Social Biography of Ethnomusicological Field Recordings: Eliciting Responses to Hugh Tracey's The Sound of Africa series", PhD thesis, University of Oxford, 2011; P. Coetzee, "The White Man's Microphone: Hugh Tracey, Types of Whiteness and African Music", Paper presented at the 1st Global Conference on Images of Whiteness, Exploring Critical Issues, Oxfordshire, UK, at http://www.inter-disciplinary.net/wpcontent/uploads/2011/06/coetzeewpaper. pdf (accessed February 2012). 
In order to explore the methodologies of archive making, I will examine three of the core activities of the archive in the time of Hugh Tracey's involvement, namely recording, cataloguing and repatriation as instances of archive making that still lend a very distinctive character to the current functioning of ILAM.

\section{The International Library of African Music (ILAM)}

Hugh Tracey initially began recording music in the mid-1930s driven by a personal fascination with the songs he was hearing. This private initiative soon developed into projects for documenting and researching traditional African music and in 1947, Tracey formed the African Music Research Unit, and one year later the African Music Society with Winifred Hoernlé. This culminated in the establishment of the International Library of African Music in 1954 based in Roodepoort, on the outskirts of Johannesburg. ${ }^{13}$ Since its establishment, ILAM has served as the headquarters of the African Music Society that edited and issued an annual journal, African Music (the only journal dedicated to African music). Today Tracey's entire collection is housed here as well as collections from other renowned ethnomusicologists, including John Blacking, Andrew Tracey, Dave Dargie and Diane Thram.

Hugh Tracey conducted several recording tours during his lifetime in central, eastern and southern parts of Africa. While on these recordings tours, spanning four decades, Tracey built up a collection that includes over 25000 field recordings; photographs and notes on the music he collected; various instruments that are for the most part still playable; and a collection of books on African music. ${ }^{14}$ This material makes ILAM the largest single archive of sub-Saharan African music in the world. From his field recordings, Hugh Tracey published two major collections: the Sound of Africa series, comprising 218 LPs, and the Music of Africa series, with 25 LPs. He also published several books, and delivered international as well as national seminars and talks. ${ }^{15}$ After Tracey's death in 1977, ILAM was moved to Rhodes University in Grahamstown and Andrew Tracey took over from his father as director in 1978. He

13. N. Lobley, "Recording the Vitamins of African Music", History and Anthropology, 22, 4 (2011), p 419.

14. At first, Hugh Tracey's field recording tours and the release of some of his recorded material was made possible through financial backing from the Gallo Record Company, and later support came from the mining industry. See H. Tracey, Catalogue, the Sound of Africa Series: 210 Long Playing Records of Music and Songs from Central, Eastern and Southern Africa, Volume I (International Library of African Music, Roodepoort, 1973), pp 4-5.

15. For examples, see H. Tracey, Chopi Musicians: Their Music, Poetry, and Instruments (Oxford University Press, Oxford, 1948); African Dances of the Witwatersrand Gold Mines (African Music Society, Johannesburg, 1952); and The Evolution of African Music and its Function in the Present Day (Institute for the Study of Man in Africa, Johannesburg, 1961). Tracey also worked as the head of programmes for the South African Broadcasting Corporation from 1936 to1947, based at their Durban studio. See Lobley, "The Social Biography of Ethnomusicological Field Recordings", p 89. 
stayed in this position until 2005 when he retired and Diane Thram was appointed as director. She was succeeded by Lee Watkins in 2016.

ILAM is housed in a purpose-built building that includes a digitisation studio, a small library, a classroom, three offices for the director and assistants as well as a temperature controlled storage room for the collection. An outside amphitheatre spans the front corner of the building and is used for music and dance performances. Walking into ILAM one is greeted by a dark ochre interior with African instruments adorning every wall: mbiras (in all shapes and sizes), pan-pipes, horizontal bow harps, wishbone lyres, antelope horns, wrist bells, stamping tubes, rattles and flutes of all kinds which are suspended from the roof above a beautiful collection of drums and marimbas. Photographs of Hugh Tracey are arranged on one wall, along with a bronze bust, a commemorative plaque in his honour and a photograph of his son Andrew Tracey.

ILAM does not only comprise a material reality that faces funding and preservation issues, but also includes various other systems and organisations, including the overarching structure of Rhodes University and the Department of Music and Musicology where Andrew Tracey and Diane Thram initiated and coordinated the award of undergraduate and post-graduate ethnomusicological degrees. ILAM is part of an international community of scholars interested in African music, but also has local community projects in various stages of completion. These initiatives, mainly steered by the three consecutive directors, have to a large extent influenced the direction of the archive and its function.

Hugh Tracey, for example, had the vision to create textbooks of "authentic" African music through his Codification and Textbook Project (1969) by documenting all the musics of sub-Saharan Africa and using these to produce teaching materials. This initiative was in turn pursued by Diane Thram, the director of ILAM and two textbooks were published in 2014 for high school students. ${ }^{16}$ Thram also developed a Hugh Tracey exhibition project called For Future Generations (2011) that travelled South Africa in 2012. Andrew Tracey developed various projects to ensure that ILAM remained a "living archive" through teaching, staging regular performances, and organising research and workshop presentations. He initiated the symposium on ethnomusicology as an annual conference in 1980 that provided an important platform for ethnomusicological scholars during the apartheid years. ${ }^{17}$ Diane Thram

16. B. McConnachie, Listen and Learn: Music Made Easy (International Library of African Music, Grahamstown, 2014); M. Carver, Understanding African Music: Listen Compose, Play, Learn (International Library of African Music, Grahamstown, 2014). This project entails the development of material for the Arts and Culture curriculum in South African schools from the archived recordings and images held at ILAM. See D. Thram, "For Future Generations: An Introduction", in D. Thram (ed.), For Future Generations: Hugh Tracey and the International Library of African Music (International Library of African Music, Grahamstown, 2010), p 17.

17. See Thram, "For Future Generations: An Introduction", p 16; C. Ballantine, "Andrew Tracey: A Colleague Reflects", in Thram (ed.), For Future Generations, p 96. In 2006 
set out to catalogue all ILAM's holdings and to garner funding for a large digitisation project which included field recordings, photographs and documents (2008). She also launched the Eastern Cape Jazz Programme (2009) in collaboration with the Red Location Museum in New Brighton outside Port Elizabeth. This initiative includes an oral history project that will become part of ILAM's holdings. The varied nature of these projects clearly demonstrates the cultural, social and personal situatedness the archive as an institution that has been collected, maintained and produced by individuals with specific interests and focus areas.

Although other collections and projects form part of ILAM's holdings, by far the largest part of the archive remains Hugh Tracey's recordings, and through ILAM's ongoing efforts Hugh Tracey's legacy and stature is most effectively disseminated worldwide. Due to its sheer physical size as well as the conceptual and musical importance of Hugh Tracey's collection to scholars and musicians and its strategic importance in leveraging funds for the archive, it remains a central part of the institution he founded. Similarly, his vision and mission remains at the core of ILAM, namely "to discover, record, analyse, and archive the music of sub-Saharan Africa, with the object of establishing a theory of music making in Africa and assessing the social, cultural and artistic values of African music".18

As alluded to above, however, Hugh Tracey's collection is not un-problematic and due to its prominence in the archive, it still infuses ILAM with its systems of classification, codification and arrangement. This problem is by no means unique to ILAM; it is a challenge faced in numerous archives that began as personal or ethnographic collections reflecting the specific interests, aims and idiosyncrasies of their creators. ${ }^{19}$ These interests tend to become embedded in the objects, catalogues, chronologies, criteria for assessing the value and projects that provide a material reality to interactions between the personal and the disciplinary in processes of power and control.

the Symposium for Ethnomusicology merged with the Musicological Society of Southern African to form the South African Society for Research in Music (SASRIM).

18. About ILAM on the official website of the International Library of African Music (ILAM). Available at http://www.ru.ac.za/ilam/ilam/aboutilam/ (accessed 10 February 2011).

19. For similar examples see the Percival Kirby Collection and the Bleek and Lloyd Collection held at the University of Cape Town Libraries, as well as the John Gubbins Collection now housed at Museum Africa, Johannesburg. For work that engages with these collections, see N. Zimmer, “Percival Kirby's Wax Cylinders: Elegy on Archiving a Deaf Spot", Social Dynamics, 41, 1 (2015), pp 101-123; G. Olwage, "Scriptions of the Choral: The Historiography of Black South African Choralism", SAMUS, 22 (2002), pp 29-45; J. Weintraub, “Some Sort of Mania': Otto Hartung Spohr and the Making of the Bleek Collections", Kronos, 32 (2006), pp 114-138; and S. Byala, A Place that Matters Yet: John Gubbins' Museum Africa in the Postcolonial World (University of Chicago Press, Chicago, 2013). 


\section{Hugh Tracey's mission}

Hugh Tracey tirelessly promoted the value and social importance of African music at a time when the public and scholarly community showed little interest in such material. This promotion was based on three principles. First and foremost, Tracey was recording and preserving material for the future to be used by African musicians and scholars. Second, these recordings were not intended simply to remain in the archive, but were envisioned to become available for use by African musicians and scholars. ${ }^{20}$ Third, in order for these materials to be respected and valued they had to be documented and transcribed. Rather than spending time on investigating the correlations between the music he was recording and the social contexts wherein it had arisen and where it was being performed, Tracey's focus was on collecting and archiving, similar to the "collect and classify" projects of early folklorist and comparative musicology. ${ }^{21}$ Because of this focus, Tracey spent very little time documenting the social contexts of the music he recorded. ${ }^{22}$ As Noel Lobley noted, "he was more inclined to document and publish outstanding examples of musicianship". ${ }^{23}$ For Tracey, the objective was to record "genuine" and "authentic" traditional African music which had not been influenced by foreign elements, an imperative that he enforced throughout his life. ${ }^{24}$

20. It should be noted that this ideal of Hugh Tracey never truly came to fruition. In a paper delivered by Andrew Tracey he notes the lack of engagement with the material by the African community itself. See A. Tracey, "ILAM and Archiving African Music", Paper presented to the Human Sciences Research Council and South African Music Libraries Association conference, held at the University of Pretoria, 12 April 1990. This unpublished document courtesy of the International Library of African Music, Grahamstown. Similarly, Lobley notes in his "The Social Biography of Ethnomusicological Field Recordings", that very few of the communities where Hugh Tracey recorded are even aware of the existence of the archive.

21. Thram, "For Future Generations: An Introduction", p 15. For example, in his Catalogue: The Sound of Africa Series, Hugh Tracey recounts: "I had discussions at the Royal College of Music in London in 1931 with two English composers, Ralph Vaughan Williams and Gustav Holst, when they encouraged me to concentrate upon discovering and recording the range and extent of African musics of which there was at that time little reliable information, to ignore for the time being any attempt to score the music and rather to record as much as funds would allow. Future musicians and students, they said, would benefit from the data gathered. Analysis of the music would then follow on a broader, sounder foundation, based upon the evidence collected on discs and not upon hearsay or romantic imagination". See Tracey, Catalogue: The Sound of Africa Series, Volume 1, p 4. There were however exceptions, for example Tracey's 1948 work, Chopi Musicians, on the Chopi of Mozambique.

22. See also D. James, "Musical Form and Social History: Research Perspectives on Black South African Music", in J. Brown (ed.), History from South Africa: Alternative Visions and Practices (Temple University Press, Philadelphia, 1991), pp 309-318.

23. Lobley, "The Social Biography of Ethnomusicological Field Recordings", pp 83-84.

24. Tracey, Catalogue: The Sound of Africa Series, Volume 1, p 18. Throughout his career Hugh Tracey emphasised the importance of preserving authentic traditional African music. See for instance an unpublished interim report of ILAM (ILAM Interim Report, 1945. Unpublished manuscript, courtesy of the International Library of African Music, 
Since Tracey recognised the "wide gap in the knowledge and understanding of African arts, and above all of African music", 25 he envisioned that his project of recording, transcribing and publishing all the musics of sub-Saharan Africa would lead to a clearer understanding of the artistic and social value of traditional African music for both "Africans" and "Europeans". ${ }^{26}$ He noted:

African music was there, for sure; but there were no marks on paper or grooves in a recoding disc to tell us, or them, what kind of music it was or how much [there was]. So the significance of African music was overlooked. ${ }^{27}$

In other words, it was through recording, writing, codification and publication that Tracey believed the African peoples, and "the outside world" would recognise "the genuineness" of indigenous African music. ${ }^{28}$

Tracey's aim of recording traditional music for future generations of African musicians and scholars left us with an expansive collection of sub-Saharan music. However, collected from within the colonial project the deeply patronising way in which he promoted his project creates discomfort in a post-colonial world. During a talk delivered to the International Folk Music Council in Biarritz in 1953, for example, Tracey stated that it became his responsibility along with other likeminded people to record the music of Africa "because we have found that the African is pathetically incapable of defending his own culture and indeed is largely indifferent to its fate". ${ }^{29}$ It is in statements such as this that the contradiction embedded in Tracey's aims comes to the surface: even though Tracey was aware of the damage caused by colonialism in Africa and therefore wanted to preserve its music, he nevertheless approached the project of salvaging these cultures in a similarly colonial manner. At times he went to great lengths to document differences in the cultures he encountered, ${ }^{30}$ but his aim of amassing as much material as possible without taking into account the social contexts involved, points to a documentation of surface qualities. Although the importance of considering the social contexts of African music in relation to its analysis has been questioned by scholars such as Kofi Agawu, such

Grahamstown). See also Tracey's codification and textbook project in H. Tracey, "Project for the Codification of African Music and the Compilation of Textbooks for Educational Purposes", African Music, 4, 2 (1968), p 8; and Tracey, Catalogue: The Sound of Africa Series, Volume 1.

25. H. Tracey, "The Significance of African Music in Central and Southern Africa", The Cramb Lectures, delivered at the University of Glasgow, 16-17 January 1967, p 3. Full typescript of unpublished lectures, courtesy of the International Library of African Music, Grahamstown).

26. Tracey, "The Significance of African Music in Central and Southern Africa”, p 3.

27. Tracey, "The Significance of African Music in Central and Southern Africa", p 3.

28. H. Tracey, Codification of African Music and Textbook Project: A Primer of Practical Suggestions for Field Research (International Library of African Music, Roodepoort, 1969), p 7.

29. H. Tracey, "The State of Folk Music in Bantu Africa”, African Music, 1, 1 (1954), p 8.

30. See Tracey, Catalogue: The Sound of Africa Series, Volume 1. 
documentation becomes important in terms of understanding the production of these recordings and its interpretation as constructed objects. ${ }^{31}$

Tracey's vision of collecting ephemeral material that had been fixed in a material reality resonates strongly with the traditional understanding of the archive as an institution mainly concerned with documents, literary texts, archaeological remains, films, sound recordings; things of a material nature that will withstand the test of time, or at least outlast the living. This understanding of archives remains true today where the imperatives of the archive constitute the preservation of written texts and material objects, the salvaging of oral histories and ephemeral knowledge before they are "lost" (that is consigned to a textual or material reality). Through recording what he judged as authentic traditional African music, Tracey similarly sought to protect African culture from disappearing.

With this in mind he devised a classification system to categorise and describe his growing collection of field recordings and provide ordered material for his final aim of repatriation. The three archival methodologies, namely recording, cataloguing and repatriation stand at the heart of Hugh Tracey's archival strategy.

\section{Hugh Tracey's recording technique}

Anthony Seeger has noted that, "no archive preserves sounds. What it preserves are interpretations of sounds - interpretations made by the people who did the recordings and their equipment". ${ }^{32}$ Recording style and equipment thus form an important technology for analysis in exploring the make-up of an ethnographic archive. Yet, as he and others have pointed out, field recordings and the methods used for making these recordings are rarely questioned by ethnomusicologists or researchers. ${ }^{33}$ Scrutiny of Tracey's recording technique reveals an idiosyncratic approach to making field recordings which allowed him to produce records of high sound and aesthetic quality. His recordings were largely determined by the

31. Tracey's methods for gathering material were questioned in later years by the first full-time ethnomusicologist employed by ILAM in 1954, John Blacking. Blacking soon realised the limitations of field methods that aimed to collect as much as possible without spending enough time to establish the relationships between the music being recorded and the wider social contexts of its performance. Tension arose between Blacking and Tracey, who never fully developed a method to document and analyse the relationship of the music to society. See Lobley, "Recording the Vitamins of African Music", p 194.

32. A. Seeger, "The Role of Sound Archives in Ethnomusicology Today", Ethnomusicology, 30, 2 (1986), p 2.

33. See Lobley, "The Social Biography of Ethnomusicological Field Recordings", where he analyses the lack of engagement with the production of field recordings as well as possible reasons for this. See also J.T. Fargion, "Recordings in Context: The Place of Ethnomusicology Archives in the 21st Century", Paper presented at the CHARM symposium, Royal Holloway, University of London, 14 to 16 April 2005, at http://www.charm.rhul.ac.uk/about/symposia/p7_2_2.html (accessed 4 January 2011); and Seeger, "The Role of Sound Archives in Ethnomusicology Today". 
possibilities his equipment afforded and by his pre-emptive framing of the music as traditional and authentic African music. He furthermore recorded music for specific audiences and purposes which included producing high quality products that could be sold or published. ${ }^{34}$

Tracey's recording equipment closely followed the development of new technologies, from recording sound directly onto aluminium discs in the 1930s to the invention of the tape recorder in the $1950 \mathrm{~s}^{35}$ In addition to cumbersome recording apparatus, he had to provide the electricity for this equipment, which meant transporting a generator weighing about half a ton through mostly difficult terrain. Due to the noise caused by the generator, Tracey had to fit a double silencer and a 100 yard long cable so that "it could be placed out of earshot behind an anthill or a hut". ${ }^{36}$ In 1949 Tracey obtained one of the first models of a studio EMI tape recorder. In order to operate it, a dome had to be constructed for the recording van so that the sound engineer could stand upright during recordings. However, the rapidly changing developments in recording technology meant that "both the weight and the fidelity of the tape recorders continually improved"37 until Tracey's equipment comprised a stereo portable transistor recorder "weighing little over nine pounds and operated by torch batteries". ${ }^{38}$

Tracey described his recording technique by comparing the microphone to a camera. He used to take, as it were, well-planned audio snapshots of the music he

34. Many of Hugh Tracey's field recordings were published and sold by the Gallo Record Company (an initial sponsor of Tracey's field trips) and one could speculate that this influenced Tracey's recording of the material. His work as a radio presenter (during his shows he used many of his own recordings) and the time he served as the director of the Natal Studios of the South African Broadcasting Corporation also would have had an impact on his insistence on quality recordings. See Tracey, Catalogue: The Sound of Africa Series, Volume 1, pp 8-9.

35. These earlier sound carriers deteriorated rapidly due to the aluminium surface and were later transferred to tape. See Tracey, Catalogue: The Sound of Africa Series, Volume 1, p 8.

36. Tracey, Catalogue: The Sound of Africa Series, Volume 1, p 10.

37. Tracey, Catalogue: The Sound of Africa Series, Volume 1, p 10.

38. Tracey, Catalogue: The Sound of Africa Series, Volume 1, p 10. Since the material in the archival vault is organised according to material type, a walk through the shelves physically tells the story of the evolution of technology and the development of new formats and carriers form the original acetate discs, pancake reels, 78rpm shellac records, long playing records, reel-to-reel tapes, DAT tapes, CDs and DVDs. All the field tapes and master tapes produced by Hugh Tracey are kept in the archive vault with the omission of a few tapes that were destroyed due to fire or damage that occurred during the move from Roodepoort to Grahamstown. The 78rpm shellac records that are kept in the vault represent a large selection of Tracey's field recordings that were published by Gallo from 1940-1950, including 675 discs containing over 1350 items. Some of these items were re-published in the Sound of Africa Series. See also Tracey, Catalogue: The Sound of Africa Series, Volume 1, p. 9. I would like to thank Diane Thram and Elijah Madiba for taking me on a tour of the facilities. 
found around him. ${ }^{39}$ However, the recording equipment imposed various limitations on the recordings. For the most part Tracey used mono-aural microphones that were only able to record in one direction (near and far) but not laterally. ${ }^{40}$ He therefore noted that the microphone should be used much like a camera to focus and select "the salient features of the music and to present them in such a way as to suggest a complete representation of the occasion".41 Attaching his microphone to a boom, Tracey "moved around among the musicians following the sounds to capture the essence of each performance with a good sound balance". ${ }^{42}$ For Tracey, recording became "an art form operating within the limitations of a frame which demands its own set of rules". ${ }^{43}$ He noted that any sound recording could thus only be an incomplete account of the whole event:

A recording, however good, is never the real thing, but a representation of the original. The problem, therefore, is how to make good recordings which will do justice to the original music, and, in some cases, do more than justice, by bringing out nuances which in the ordinary way might not be noticed by the audience. ${ }^{44}$

Due to the emphasis Tracey placed on making "good" recordings and the restrictions of his microphone, it was necessary for him to plan the content of recording in advance and sometimes to re-arrange the musicians to suit acoustic conditions and accommodate the technical limits of his recording equipment. For similar reasons he also tried to avoid recording in large crowds or during rituals, which meant that he had to stage performances outside of their social contexts. ${ }^{45}$ The recording equipment further restricted recording on account of its limited recording time. Tracey therefore developed a system whereby he controlled the performances via hand signs, signalling for the musicians to start, stop and fade, and advised against recording full repetitive songs, regardless of whether this was an essential part of the musical expression. ${ }^{46}$ Noel Lobley points out that "although Tracey aspired to find a method of capturing the folk music of Africa within its actual settings, he ... began to create artificial constructions, recordings that were not necessarily accurate records of social events". ${ }^{47}$ Tracey's recordings were thus fundamentally shaped by the act of

39. Tracey, Codification of African Music and Textbook Project: A Primer of Practical Suggestions for Field Research, p 30.

40. H. Tracey, "Recording African Music in the Field", African Music, 1, 2 (1955), p 7; Tracey, Codification of African Music and Textbook Project: A Primer of Practical Suggestions for Field Research, p 34.

41. Tracey, "Recording African Music in the Field", p 7.

42. Thram, "For Future Generations: An Introduction," p 12.

43. Tracey, "Recording African Music in the Field", p 7.

44. Tracey, "Recording African Music in the Field", p 7.

45. Tracey, Codification of African Music and Textbook Project: A Primer of Practical Suggestions for Field Research, pp 31-32.

46. Tracey, Codification of African Music and Textbook Project: A Primer of Practical Suggestions for Field Research, pp 31-32; Tracey, "Recording African Music in the Field", p 8.

47. Lobley, "The 'Sound of Africa' for Future Listening", in Thram (ed.), For Future Generations, p 174. 
recording that dictated the possibilities of archiving, possibilities that produced as much as it recorded the event. ${ }^{48}$

Tracey's final aim of publishing and distributing these recordings further influenced him to select musicians and to arrange the music to capture and present what he thought was the most aesthetically pleasing versions of songs. He was aware that his recording methodology influenced his recordings, noting: "my recording, my registration of the music, must contain some element of choice which was not African but foreign". ${ }^{49}$ Yet, Tracey never sought to analyse his role in potentially distorting the "authentic" events he wished to capture. These recordings should therefore be considered as constructions shaped and influenced by Tracey's worldview and culture, the technologies he used, his intention to sell the final product commercially and his firm ideas about "authenticity" and "genuine" African music.

\section{Classification and the Sound of Africa Series}

As the number of Tracey's recordings increased, he had to develop his own classification system. This culminated in the catalogue for the Sound of Africa Series, comprising 210 albums and more than 3100 field recordings. ${ }^{50}$ These recordings were selected by Tracey as representative of the music of sub-Saharan Africa from his more than 25000 field recordings recorded during seventeen recording tours undertaken from 1948 to 1970 . This series was thus selected from the bulk of Tracey's recordings, and was published to serve educational and academic purposes. ${ }^{51}$

The classification system Tracey developed was intended "to indicate the authenticity of the composition which follows musical and linguistic rules undistorted by foreign influences". ${ }^{52}$ When he began recording and selecting items for this series in 1948, he found that "no such system for African conditions existed" and he therefore had to devise his own. ${ }^{53}$ He subsequently decided to categorise his recordings according to the purpose or function of the songs, but was aware that his system was not unproblematic since "no system is likely to prove faultless as so many interpretations can be given to a single complex item". 54

48. J. Derrida, Archive Fever: A Freudian Impression (University of Chicago Press, Chicago, 1996), p 17.

49. Tracey, "The Significance of African Music in Central and Southern Africa", p 3.

50. After Hugh Tracey's death, Andrew Tracey added a further eight recordings of his own fieldwork to the series to bring the total number to 218 .

51. Tracey, Catalogue: The Sound of Africa Series, Volume 1, p 10. Another series of 25 albums was also released. It was entitled The Music of Africa Series and was published as a commercial product aimed at public consumption, in contrast to the Sound of Africa Series, which was intended for educational and academic purposes.

52. Tracey, Catalogue: The Sound of Africa Series, Volume 1, p 18.

53. Tracey, Catalogue: The Sound of Africa Series, Volume 1, p 18.

54. Tracey, Catalogue: The Sound of Africa Series, Volume 1, p 18. Tracey's decision to classify the recordings according to the purpose or use of songs, highlights the 
Tracey's classification system was based on three main descriptive groups: "language and dialects"; "musical instruments"' and "type of performance". 55 These groups were then divided into specific categories. The performance category, for example, is divided into 28 categories, which were in turn sub-divided into 145 specific performance types. ${ }^{56}$ The 28 categories of performance types that Tracey identified include songs by "children and young people"; "initiation, puberty and circumcision songs"; "school songs"; "love songs"; "wedding songs"; "burials, wakes and laments for the dead"; "religious and superstitious pagan" songs; the songs of "native Christian churches"; "Mohammedan songs"; "divination and spiritualism" songs; "spell binding and breaking" songs; "social and political" songs; "morality" songs; "fighting and military" songs; "work or occupational" songs, including "domestic", "pastoral" and "labour" songs; "ballads and songs for general entertainment including concerts"; "laments"; "self-delectative" songs "sung for one's own delight"; "dance songs"; stories and riddles and "rhythms"; and "instrumental tunes without words". ${ }^{57}$ As an example of the further sub-division, "songs for general entertainment" is divided into 13 categories, including songs relating to "scandals"; "historic" songs "recalling famous occasions"; "praise songs"; "sentimental, emotional, wistful, nostalgic" songs; "adaptations of foreign songs (non-African)"; "humorous" songs; "pornographic, bawdy songs"; "party songs" and "begging, street selling" songs. ${ }^{58}$

Additionally, Tracey also employed another classificatory system designed to assess the relative merits and potential audiences for all of his recordings, divided under five headings, with T standing for "territorial entertainment"; C for "continentwide entertainment"; A for "anthropological interest"; L for "linguistic material" and $\mathrm{M}$ for "musical interest". ${ }^{59}$ Capital letters were used to refer to items judged by Tracey "to be of special musical value". ${ }^{60}$ This second level of classification was Hugh Tracey's personal system in order for him to remember the recordings. As a private mnemonic system, Tracey never saw the need to specify what criteria he used to grade these recordings as aesthetically pleasing or not, as good or bad, worthy of publication or not, it was based entirely on his own subjective judgement. ${ }^{61}$ Although

problems inherent in Tracey's recording technique of staging performances and not documenting the social contexts of songs or events.

55. Tracey's classification system included a four-part, colour-card index and reference system to help users organise their Sound of Africa recordings as well as allow for cross-referencing by language and dialects, musical instrument, type of performance and numerical order. See Tracey, Catalogue: The Sound of Africa Series, Volume 1, pp 19-23).

56. Tracey, Catalogue: The Sound of Africa Series, Volume 1, pp 19-23.

57. Tracey, Catalogue: The Sound of Africa Series, Volume 1, pp 19-23.

58. Tracey, Catalogue: The Sound of Africa Series, Volume 1, p 22.

59. Tracey, "The State of Folk Music in Bantu Africa", p 2.

60. Lobley, "The 'Sound of Africa' for Future Listening”, p 224.

61. In consulting the texts that set out Hugh Tracey's classification systems, namely African Music Transcription Library: Librarian's Handbook (Gallo (Africa) Ltd, Johannesburg, 1952); Codification and Textbook Project: A Primer of Practical 
one might argue that these classifications were personal and thus not meant to be used by the general public, this system can be found alongside his other classificatory system in the two volume catalogue of his Sound of Africa series, at once making the personal and private, public. It created the possibility that this subjective classification system could become naturalised in processes of objectification such as monographs, articles, treaties and manuals without consideration of its genesis. As Olivia Da Cunha has noted, these private systems

are transformed by contingent, posthumous and unexpected uses, such as when object, documents and rhetorics on the "other" preserved in archives belonging to ethnographers become part of the construction of an "ethno-history" by historians, anthropologists, descendants of the studied groups/subjects or the institutions/movements that "represent" them. ${ }^{62}$

In these systems of classification the workings of the archive can be recognised as processes of judgement and objectification. These systems are designed to fix meaning, set limits and impose systems of "order on apparent randomness", presenting a system of thought exotic and foreign to those outside it. ${ }^{63}$ The archive becomes a "product of judgement", ${ }^{64}$ in which we can observe the confluence of the personal and the ideological in its construction. Considering these processes can, as Kofi Agawu argued, "have decisive consequences on the work of understanding. Even the most apparently transparent categories already enshrine alternatives insofar as they are propped up by certain presuppositions". 65

\section{Codification and the Textbook Project}

As a textual corollary to his Sound of Africa Series, Hugh Tracey planned an ambitious project called the Codification and Textbook Project (1969). Although this project failed to materialise due to the absence of funding and the grand scope of Tracey's vision, the principles of this project encompass most of Tracey's other projects. The Codification and Textbook Project was designed as a ten-year research plan divided into five years of collecting and then a further five years of analysis and publication. ${ }^{66}$ Tracey intended to methodically document all the musics of sub-Saharan Africa to "form a basis of authentic data" from which to produce teaching materials for schools. ${ }^{67}$ This would include a complete reference book and larger research units in

Suggestions for Field Research (1969); and Catalogue: The Sound of Africa Series (1973), no mention is made of the criteria used to judge recordings.

62. O.M.G. da Cunha, "Imperfect Tense: An Ethnography of the Archive", Mana, 10, 2 (2004), pp 287-322, at http://socialsciences.scielo.org/pdf/s_mana/v1nse/ scs_a01.pdf (accessed 2 July 2011).

63. J. Taylor, "Holdings: Refiguring the Archive", in Hamilton et al. (eds), Refiguring the Archive, p 248.

64. A. Mbembe, "The Power of the Archive and its Limits", in Hamilton et al. (eds), Refiguring the Archive, p 20.

65. Agawu, Representing African Music, p 38.

66. Tracey, Codification of African Music and Textbook Project, $\mathrm{p} 12$.

67. Tracey, Codification of African Music and Textbook Project, $\mathrm{p} 12$. 
Africa. ${ }^{68}$ One of the main outcomes envisioned by Tracey of this codification project was the "establishment of accepted and logical terms suited to African phenomena". ${ }^{69}$ Tracey wanted to give "African musicians a certain sense of background and continuity to their art"70 and "bring African music into the field of African education in its broadest sense". ${ }^{71}$ It was through transcriptions, research and educational material that Tracey believed Africans and "the outside world" would recognise "the genuineness" of indigenous African music. ${ }^{72}$ Tracey wrote in 1968 that:

the major objective of the codification of African music is to provide African ... musicians with a working knowledge of the theory of their own art and a suitable musical literacy which is essential once they are beyond the stage of composing and performing by ear alone. ${ }^{73}$

He believed that this recognition will "provide deep satisfaction to African musicians in the future in having their own poetry and musics culturally recognised for their intrinsic merit". ${ }^{74} \mathrm{He}$ also noted that this project will "help Africans to realise their potential through their music, so that they may be a more fulfilled people". ${ }^{75}$ Although Tracey hoped that this project would provide scientific merit through creating cultural products that could be used by African musicians and scholars in the future, ${ }^{76}$ the deeply paternalistic tone of these statements has been widely critiqued by scholars as a form of "neo-colonialism". ${ }^{77}$ Paulette Coetzee has noted that in this discourse whiteness "portrays itself as central to knowledge production and reception. African musicians are objectified as part of the discovery, requiring Western representation and dissemination".78 Tracey viewed Western systems of theory, analysis, notation and textuality as imperative to ensure the continued existence of African art. He wanted to protect "African culture" and provide Africans with a lasting legacy of what he considered as disappearing traditional African music

68. Tracey, Codification of African Music and Textbook Project, pp 6, 52.

69. Tracey, Codification of African Music and Textbook Project, $\mathrm{p} 8$.

70. Tracey, Codification of African Music and Textbook Project, $\mathrm{p} 6$.

71. Tracey, Codification of African Music and Textbook Project, $\mathrm{p} 7$.

72. Tracey, Codification of African Music and Textbook Project, $\mathrm{p} 7$.

73. Tracey, "Project for the Codification of African Music and the Compilation of Textbooks for Educational Purposes", p 8.

74. Tracey, "Project for the Codification of African Music and the Compilation of Textbooks for Educational Purposes", p 8.

75. Tracey, "Project for the Codification of African Music and the Compilation of Textbooks for Educational Purposes", pp 7, 8.

76. Tracey, "Project for the Codification of African Music and the Compilation of Textbooks for Educational Purposes", p 7.

77. Peek, Book Review of H. Tracey, (with A. Tracey and Kubik), Codification of African Music and Textbook Project, p 505. See also. Agawu, “Contesting Difference”, p 230; Erlmann, African Stars, p 1; and Pantaleoni and A. Tracey, Book Review of H. Tracey, Codification of African Music and Textbook Project, $\mathrm{p} 96$.

78. Coetzee, “The White Man's Microphone”, p 5. 
in which "they" could express themselves. The ILAM archive thus functions as both a material place of preservation as well as a site of power and control. ${ }^{79}$

Tracey was often accused of "creating an image of African music that was biased or even out-dated". ${ }^{80}$ He wanted to protect and preserve traditional African music against what he considered the threat of urban music, radio and the import of gramophone records. ${ }^{81}$ Garrett Felber points out that this view of "musical hybridity as culturally impure" led Tracey to resist "recording and preserving the sounds of an urban, non-tribal working class, and instead helped to create a divisive and often imagined tribal world that fetishized ethnic purity". ${ }^{82}$ Although Tracey was aware that his choice of what material to record must of necessity contain "some element of choice which was not African but foreign," 83 he never considered what the implications of this might be for the archive, and some scholars have pointed out that Tracey's recorded collection was inevitably "divorced from an indigenous African audience ... always destined to serve Western academic agendas". ${ }^{84}$

Furthermore, Lobley notes that since Tracey "regularly dismissed anthropological methods and theories," his focus fell on "recording music as a decontextualised object, at the expense of wider social analysis". ${ }^{85}$ When considering this critique, Tracey's aim of returning his recordings to communities so as to inspire them and to be used by future generations of African musicians, becomes fraught with contradictions. His vision was to repatriate constructed recordings of what he judged to be "authentic traditional African music", organised according to Western systems of theory and analysis into categories - to give them back to the African communities where they had originated.

79. Derrida, Archive Fever, $\mathrm{p} 11$.

80. Lobley, "The 'Sound of Africa' for Future Listening”, p 235.

81. Tracey, "The State of Folk Music in Bantu Africa", p 11; Erlmann, African Stars, p 1. Tracey wrote in his Catalogue: The Sound of Africa Series, Volume 1, p 18, that "Winds from foreign regions may bend the bough, but the object of this survey is to illustrate the nature of the tree of African music standing with its roots in its own African soil". For other work on Tracey's views of traditional/urban music see Gwen Ansell who points out that "Tracey's distaste for syncretic music brought him very close to the official view that black workers were only temporary city dwellers and should stay true to the 'pure' tribal music of their official rural homelands". See G. Ansell, Soweto Blues: Jazz Popular Music and Politics in South Africa (Continuum International Publishing, New York and London, 2005), p 51. See also the article by Garrett Felber where he argues that Tracey's strategies of promoting music "that encouraged an imagined tribal purity over an urban working-class hybridity" supported the apartheid government policies of retribalisation. See Felber, "Tracing Tribe”, p 34.

82. Felber, "Tracing Tribe," p 43.

83. Tracey, "The Significance of African Music in Central and Southern Africa", p 3.

84. Lobley, "Recording the Vitamins of African Music", p 423; Pantaleoni and A. Tracey, Book Review of H. Tracey, Codification of African Music and Textbook Project, p 96.

85. Lobley, "The Social Biography of Ethnomusicological Field Recordings", p 8. See also A. Hoffmann, "Introduction: Listening to Sound Archives", Social Dynamics, 41, 1 (2015), p 79. 
The "thematic limits" 86 of "authentic" and "genuinely traditional" imposed by Tracey, as well as the constructed categories of value judgement, act as conduits of Tracey's own ideological pre-conceptions of what African music should be. He emphasised the legitimacy of written and recorded modes of knowledge over and above oral/aural conceptions thereof and subsequently built an archive geared towards salvaging or "capturing" the music and instruments of what he considered to be disappearing cultures. This resulted in a highly constructed and uncontested archival record.

The archive clearly functions not only as a source, but also as an institution that informs what has been collected and controls how this knowledge of the "other" is presented and valued - all of which has a direct bearing on the interpretation of its holdings. Tracey's project and the kind of archive that the International Library of African Music became through historical contingency is a case point of how the archive becomes a structure of power and control through appraisal, codification and classification. If the archive is subsequently considered bound through these systems that limit, restrict, construct and value, how can archives move beyond this teleological bind to function as democratic institutions open to multiple narratives and readings?

\section{Performing the archive}

Although it is generally accepted that archivists are not impartial custodians, but active shapers of the record and social memory, ${ }^{87}$ archival practice in South Africa is still mainly defined in terms of custodianship, physical material and places of custody. ${ }^{88}$ Archival discourses remain divided, with archival practice, or work that deals with the archive as a neutral and "solid place of material storage and accumulation," on the one hand, and on the other hand with work that sees the archive as an "unstable and ever-changing site always open to the exigencies and recasting of the future-to-come, on the other". ${ }^{99}$ This duality is often used to justify archival work as physical and pragmatic within systems that serve these purposes, while critical engagements, interventions and creative projects are left to the devices of the academe and artists.

86. Da Cunha, "Imperfect Tense: An Ethnography of the Archive".

87. For examples, see Burton, "Introduction", in Burton (ed.), Archive Stories, p 5; Kaplan, "Many Paths to Partial Truths", p 217; Harris, Exploring Archives, pp 90-91; V. Harris, "Introductory Essay: Refiguring the Archive", S.A. Archives Journal, 40, 1998, p 2.

88. For examples see V. Harris, "'Something is Happening Here and You don't Know What it is': Jacques Derrida Unplugged”, Journal of the Society of Archivists, 26, 1 (2005), p 135; V. Harris, "Nascence, Renaissance and the Archive in South Africa", S.A. Archives Journal, 42, 2001-2002, p 4; Harris, Exploring Archives, p 91; V. Harris and S. Hatang, "Archives, Identity, and Place: A Dialogue on What it (might) mean(s) to be an African Archivist", ESCARBICA Journal, 19 (2000), pp 41-60.

89. S. van Zyl, "Psychoanalysis and the Archive: Derrida's 'Archive Fever'”, in Hamilton et al. (eds), Refiguring the Archive, p 53. 
However, through the main exposition of this article, it becomes clear that these systems and archival methodologies are "man-made and artificial," 90 shaped by the social, personal, political, economic and technical, which in turn structures and shapes the material preserved in archives. ${ }^{91}$ Archives and archivists can therefore not stand impartial and neutral towards the systems they use. In addition, Amanda Strauss has pointed out that in societies where national memory is contested "inaction causes harm" and archival neutrality "becomes an untenable position". 92

Through exploring processes of archive making, similar to the case study presented here, nexuses of tension can be exposed where we can begin bridging the ontological and epistemological extremes embedded in the opposing views of what an archive is and should do. It can stimulate the possibility of engaging archival institutions both as places of custodianship, and at the same time, as sites that challenge the very systems that make this custodianship possible. It is here, within these nexuses, that the possibility lies for archives to start taking part and engaging critically with their practice in ways that explore opportunities for opening up their collections to multiple interpretations. ${ }^{93}$

In, for example, considering the interrogation of the processes of archive making used by Hugh Tracey whereby Western systems of collecting and classifying are seen as imperative to ensure the existence of musical traditions in sub-Saharan Africa, inserting other ways of knowing into the archive could challenge the authority of the archival system and material as created by Tracey. Diana Taylor, for example, examines both the archive of supposedly lasting materials (texts, documents and objects), and the so-called ephemeral repertoire of embodied practice or knowledge

90. See also J. Evans and S. McKemmish, "Self-determination and Archival Autonomy: Advocating Activism", Archival Science, 15 (2015), p 347.

91. To some extent, Tracey was aware of the limitations of the systems he designed, noting how his choices would necessarily reflect "foreign" considerations; that he had to make classification choices when a song was, for example, originally composed as a love song but also used for dancing. See Tracey, Catalogue: The Sound of Africa Series, Volume 1, p 18. However, Tracey never considered the implications of these processes and his choices for the archive that he subsequently collected. He noted for example in the Sound of Africa Catalogue that his classifications were "reasonably adequate for the present" (see Tracey, Catalogue: The Sound of Africa Series, Volume 1, p 18).

92. A. Strauss, "Treading the Ground of Contested Memory: Archivists and the Human Rights Movement in Chile", Archival Science, 15 (2015), p 371.

93. Annette Hoffmann, for example points out that "sound collections are often 'buried' in archives assigned to specific disciplines and ... have therefore rarely been deemed relevant for other areas of research. This led to a considerable neglect of acoustic archives in research in the humanities". See Hoffmann, "Introduction: Listening to Sound Archives", p 74. Similarly, Niklas Zimmer cautions that records often "fall silent" due to a lack of "sustained, critical engagement that takes cognisance of the ethical responsibilities involved in working with the materials invested in the institutional body". See Zimmer, "Percival Kirby's Wax Cylinders”, pp 117-118. 
(dance, rituals and songs). ${ }^{94}$ She does not view the archive and the repertoire as opposing structures, but as two constructions, each working in the silences and fractures of the other. Looking beyond the binary of written/performed, material/ephemeral, Western/Other, Taylor convincingly shows how both the archive and repertoire exceed "the limitations of the other", for instance when dealing with the reality of disappearance. ${ }^{95}$ Whereas it is true that individual performances disappear, and that if captured via archival strategies they might outlive the live, archival strategies can never capture the live event which means that it can never be "transmitted through the archive". ${ }^{96}$ A recording of a song or performance cannot replicate the event itself; it will always remain but a fraction and a textualisation of the performance even though "it often comes to replace the performance as a thing in itself". ${ }^{97}$ Although the archive has overwhelmingly been conceptualised as the final keeper of knowledge because it claims immunity to destruction (at least for a certain time-period), Taylor points out that what is often negated in this argument is that performances "also replicate themselves through their own structures and codes ... embodied and performed acts generate, record and transmit knowledge". 98

What is presented to us here is the possibility of challenging the Western paradigm that seeks to capture and preserve, to codify, classify and objectify. Acknowledging performance as an important system of knowing and transmitting knowledge would amount to a radical shift in an archival practice only concerned with the written, captured and frozen. It would allow for dynamic institutions involved in the active curation of performance; institutions concerned with both material and repertoire where the latter is not confined in written and textual documents but understood as living, changing and breathing sites and spaces for the transmission of knowledge. During the 1980s, ILAM did start moving in this direction when the then director, Andrew Tracey, made attempts to align the curation of the repertoire with ILAM's function. ${ }^{99} \mathrm{He}$ had a Xhosa cultural village, complete with

94. D. Taylor, The Archive and the Repertoire: Performing Cultural Memory in the Americas (Duke University Press, Durham and London, 2003), p 9.

95. Taylor, The Archive and the Repertoire, p 20.

96. Taylor, The Archive and the Repertoire, $\mathrm{p} 20$.

97. Taylor, The Archive and the Repertoire, p 20. Even though other cultural practices (such as oral history) are recognised as knowledge systems, the focus is always and without fail on the importance, necessity and responsibility to "capture" these knowledge systems before they disappear. The written text is still considered as the only valorisation of knowledge, the final keeper thereof. Repertoire is not recognised as a valuable site for the safekeeping and transmission of knowledge in itself.

98. Taylor, The Archive and the Repertoire, pp 20-21. See also the work of Jones, Abbott and Ross, "Redefining the Performing Arts Archive", pp 165-171. Their work builds further on Taylor's idea, namely that each performance is part of an ongoing process that "is constantly feeding back on itself [so that t] he identification of immaterial traces that are in a constant state of re-enactment counters the notion that performance disappears". See Jones, Abbott and Ross, "Redefining the Performing Arts Archive", p 167.

99. Andrew Tracey noted that the problem of the archive is "precisely the intangible factors that archives cannot capture". He goes even further by arguing that "an 
kraal and huts, built just behind ILAM. This space was regularly populated with musicians and storytellers, but had to be taken down eventually due to vagrants from the community who took up residency in the huts.

Clearly not without its challenges, this kind of programme, if sustained, could enhance the archive's expertise by de-centring the value assigned to material through archival processes. Performing the archive literally, could lead to alterative readings and enhance understanding of material locked into the closed system of archival holdings. What loses authority in this process is not the material, but the system of authority. Such a programme would extend archival practice beyond the notion that creating collections of greater diversity is enough, into spaces where the epistemic constraints inherent in archival systems is challenged. ${ }^{100}$

\section{Conclusion}

In writing about critical research on archives, leading archival scholars Joanne Evans and Sue McKemmish note that "in moving beyond insight and critique to transformative outcomes, a critical approach has the potential to enrich interventionist methodologies". ${ }^{101}$ It is with an understanding of the ideological underpinnings, deep-seated assumptions, and structural contradictions of these practices and systems, that archives can use their holdings to question the very systems that created their holdings, opening their mechanisms to scrutiny and creative intervention. Through such practices, archives can play a transformative role in the pursuit of dealing with contested pasts and legacies in South Africa.

Conducting a critical reading of the complex relations between material, system and epistemology in Hugh Tracey's collection, reveals the complexities inherent to the archival holdings. It opens up nodes of tension that could enable ILAM to move from parochial content-related exchanges to become an innovative leader in the much broader local and international discourse on post-colonial thinking and the archive. Establishing the limits of systems and encouraging such a critical discourse, far from diminishing the value of an institution such as ILAM, gives an archive possibilities to reclaim the relevance of its collection in the present moment and for the future in nuanced and self-reflective ways.

However, the view and application of archives will first need to shift in practice from repositories of purely informational value to a wider understanding of how those records came to be there, how they were created, by whom and what the implications are for users and interpretations of these records. In music archives,

archivist has to realise that what he is preserving is perhaps not the most important thing, which is the living tradition". See A. Tracey, "ILAM and Archiving African Music", p 3.

100. See also C. Hamilton, V. Harris and G. Reid, "Introduction", in Hamilton et al. (eds), Refiguring the Archive, pp 11-12; Evans and McKemmish, "Self-determination and Archival Autonomy", p 347.

101. Evans and McKemmish, "Self-determination and Archival Autonomy", p 341. 
engaging with performances that speak to the aporias in the archive, opens up a myriad of opportunities for projects, outreach initiatives, textbooks, exhibitions, publications and repatriation projects that engage with the archive as a source and as an authority, projects that question the epistemic validation of certain forms of knowing above others. To make this possible, archivists will have to reject the perceived stance of neutrality and passivity and accept an active role in the construction of the archive, taking on critical engagement with their holdings not as a supplement to their daily routine, but as an integral part of their work as archivists.

Adopting practices such as these, archives with ideologically and politically charged holdings have the potential to challenge simplistic narratives about the past and to empower the public to develop new narratives to engage with the present. 